RESEARCH ARTICLE

\title{
Level of Depression, Anxiety, and Stress of College Students in Indonesia during the Pandemic COVID-19
}

\author{
Nurul Romadhona, Susan Fitriyana, Raden Ganang Ibnusantosa, Titik Respati \\ Department of Public Health, Faculty of Medicine, Universitas Kristen Maranatha, Bandung, Indonesia
}

\begin{abstract}
The COVID-19 pandemic has caused a shift in learning methods to online. The obstacles felt by college students can have an impact on mental health. However, data on student mental health in Indonesia during the pandemic is still limited. This study describes the depression, anxiety, and stress of college students in Indonesia during the COVID-19 pandemic. This research method is descriptive, conducted on college students in Indonesia from July to August 2021. Sampling is done by voluntary sampling collection, with 258 respondents. The research instrument is a questionnaire of characteristics and depression, anxiety, stress scale (DASS) 42 in the form of Google Form. Data analysis using Microsoft Excel. The results of the research on the characteristics of the most respondents, namely, age in the range of 20-24 years (85.3\%), female (64.7\%), from Java (6o.8), third grade (66.7\%), living with parents (74.8\%), and from the faculty of medicine (23.3\%). More college students are not depressed (55.0\%) or not stressed (57.4\%) than those who are depressed or stressed. However, more college students experience anxiety than those who are not anxious, 60.1\%. Based on the level, most college students experienced moderate depression (12.8\%), very severe anxiety (20.9\%), and severe stress (13.6\%). This study concludes that most college students experience moderate depression, very severe anxiety, and severe stress. The success of online education depends on several factors, such as basic technical skills and the ability to access hardware and software, good self-motivation, and the availability of a conducive learning environment. This problem can have an impact on the mental health of college students.
\end{abstract}

Keywords: Anxiety, college students, depression, online learning, stress

\section{Tingkat Depresi, Kecemasan, dan Stres pada Mahasiswa di Indonesia selama Masa Pandemi COVID-19}

\begin{abstract}
Abstrak
Pandemi COVID-19 menyebabkan peralihan metode pembelajaran menjadi daring. Terdapat manfaat dan kendala pada pembelajaran daring. Kendala yang dirasakan mahasiswa dapat berdampak pada kesehatan mental. Data kesehatan mental mahasiswa di Indonesia selama pandemik masih terbatas. Penelitian ini bertujuan menggambarkan depresi, kecemasan, dan stres pada mahasiswa di Indonesia selama masa pandemi COVID-19. Metode penelitian adalah deskriptif yang dilakukan pada mahasiswa di Indonesia pada Juli hingga Agustus 2021. Pengambilan sampel dengan cara sampling sukarela dengan jumlah responden 258 orang. Instrumen penelitian berupa kuesioner karakteristik dan depression, anxiety, stress scale (DASS) 42 dalam bentuk Google Form. Analisis data menggunakan Microsoft Excel. Hasil penelitian karakteristik responden yang terbanyak, yaitu usia pada rentang 20-24 tahun (85,3\%), perempuan $(64,7 \%)$, berasal dari Pulau Jawa $(60,8)$, tingkat tiga $(66,7 \%)$, tinggal bersama orangtua (74,8\%), dan dari fakultas kedokteran (23,3\%). Lebih banyak mahasiswa yang tidak depresi (55,0\%) atau tidak stres $(57,4 \%)$ daripada yang depresi atau stres. Namun, lebih banyak mahasiswa yang mengalami kecemasan daripada yang tidak cemas, yaitu 60,1\%. Berdasar atas tingkatannya, mahasiswa paling banyak mengalami depresi sedang (12,8\%), kecemasan sangat berat (20,9\%), dan stres berat (13,6\%). Simpulan penelitian ini adalah sebagian besar mahasiswa mengalami depresi sedang, kecemasan sangat berat, dan stres berat. Keberhasilan pendidikan daring bergantung pada beberapa faktor seperti keterampilan teknis dasar dan kemampuan mengakses perangkat keras dan lunak, motivasi diri yang baik, serta ketersediaan lingkungan belajar yang kondusif. Terkendalanya hal ini dapat berdampak pada kesehatan mental mahasiswa.
\end{abstract}

Kata kunci: Depresi, kecemasan, mahasiswa, pembelajaran daring, stres

Received: 11 August 2021; Revised: 22 December 2021; Accepted: 30 December 2021; Published: 31 December 2021

Correspondence: Nurul Romadhona, dr., MMRS. Department of Public Health, Faculty of Medicine, Universitas Islam Bandung. Jln. Tamansari No. 22, Bandung 40116, West Java, Indonesia. E-mail: nromadhonadr@gmail.com 


\section{Introduction}

The COVID-19 pandemic has hit countries in the world..$^{1,2}$ To break the chain of the COVID-19 virus, the authorities instruct the public to selfquarantine at home for healthy and self-isolate for those diagnosed and symptomatic in various countries. There are restrictions on working outside the home and school closures in more than 100 countries worldwide. ${ }^{3}$

Similarly, throughout Indonesia, learning activities at schools and universities were also stopped as stated in the Circular from the Minister of Education and Culture Number: 36962/MPK.A/HK/2020 dated March 17, 2020, regarding Online Learning and Working from Home to Prevent the Spread of Corona Virus Disease (COVID-19). ${ }^{4}$

Cessation of learning activities in schools, including universities, causing the shift to learning from home. ${ }^{4}$ Online learning in the form of distance learning is an alternative and a necessity in organizing learning for students. ${ }^{5}$

The benefits of online education include being able to reach college students broadly, allowing for more flexible learning interactions, increasing the intensity of learning interactions between college students and lecturers, and facilitating the refinement and storage of learning materials.., 6

In addition to the perceived benefits, some obstacles arise. College students may encounter online learning. The blocks are network instability and technological constraints, lack of belonging and connectedness, lack of student involvement, delivery of material online is not as straightforward as when face to face, changes to the academic schedule, 7 and Finally, the online learning atmosphere is not conducive. ${ }^{3,6-8}$

Online learning has an impact on college students. Results research conducted by the nonprofit organization Active Minds on 2,000 college students found that one in five respondents experienced a significant deterioration in their mental health during the pandemic. Stressors related to this are online learning, social distancing, and health and economic impacts that cause anxiety, resulting in long-term stress. ${ }^{9}$ The results of a review of various journals show that changes in learning methods can cause mental health problems for college students. Previous research results on 30 college students in Samarinda, namely college students with low parental income causing anxiety due to problems buying internet quota to participate in online learning. ${ }^{10}$

Research results from a review of 10 journals show an increase in stress and anxiety in college students during the COVID-19 pandemic. ${ }^{7}$ The results of a literature review by Kartika show that psychological problems that college students often experience are excessive anxiety, stress, and depression. The cause of this problem, among others, is many college assignments, do not understand the course material, authoritarian task groups could not meet with relatives, problematic internet network, saturated with online learning, learning-conducive environment, and changes in the family. ${ }^{11}$ Empirical studies conducted in various countries, namely Bangladesh, China, France, the UK, and the US, found that most college students suffer from mental disorders such as depression, anxiety, and even suicidal thoughts. 7,12

Another research results stated that mental health is the key to student success in completing studies. $^{13}$ The mental health status of college students during the pandemic must be monitored for evaluation. It is the primary data for the psychological intervention approach of college students so that academic performance is well maintained. There is not much data regarding the mental health picture of college students in Indonesia. This data is the basis for the government determining policies related to the pandemic. ${ }^{14}$ This study describes the overview of depression, anxiety, and stress in college students in Indonesia during the pandemic COVID-19.

\section{Methods}

The design of this research is descriptive. This research was conducted on college students in Indonesia from July to August 2021. Sampling was carried out by voluntary sampling, with 258 respondents. The study was conducted by spreading Google Forms through social media. Google Form contains characteristics and questionnaires for depression, anxiety, stress scale (DASS) 42. Respondents' characteristics consist of age, gender, regional origin, academic level, who live with, and faculty. The DASS 42 questionnaire has been adapted into Indonesian by Damanik ${ }^{15}$ and has passed the validity and reliability tests.

There are 42 questions where each statement can indicate three conditions, namely depression 
Table 1 Categories of Depression, Anxiety, and Stress

\begin{tabular}{lccc}
\hline Categories & Depression & Anxiety & Stress \\
\hline Normal & $0-9$ & $0-7$ & $0-14$ \\
Mild & $10-13$ & $8-9$ & $15-18$ \\
Moderate & $14-20$ & $10-14$ & $19-25$ \\
Severe & $21-27$ & $15-19$ & $26-33$ \\
Very severe & $\geq 28$ & $\geq 20$ & $\geq 34$ \\
\hline
\end{tabular}

in statements $3,5,10,13,16,17,21,24,26,31,34$, $37,38,42$; anxiety on numbers $2,4,7,9,15,19$, $20,23,25,28,30,36,40,41$; and stress numbers $1,6,8,11,12,14,18,22,27,29,32,33,35,39$.

There are four answer choices provided for each statement. A value of o means that it does not match the same respondent once, or never, a score of 1 means that it fits the respondent to a certain degree, or sometimes, a score of 2 means that it provides the respondent to a considerable extent, or quite often, and a score of 3 means that it fits the respondent very well, or very often.

The statements are then summed up according to the grouping of depression, anxiety, and stress reports, then put into the categories in Table $1 .^{14}$

Data were analyzed and processed using Microsoft Excel. This research has received ethical approval from the Health Research Ethics Committee of Universitas Islam Indonesia with the number: 101/KEPK-UNISBA/VII/2021.

\section{Results}

An overview of student characteristics in Indonesia during the pandemic can be seen in Table 2. Most respondents are in the range of 2024 years, which is $85.3 \%$. The number of female respondents is more than males, $64.7 \%$. Most of the respondents came from the island of Java, namely $60.8 \%$. Most respondents are at level three, which is $66.7 \%$. Most of the respondents live with their parents, which is $74.8 \%$. As for those who live with other people, such as boarding schools, dormitories, relatives, while those who live alone, such as boarding houses, own houses, prayer rooms, mosques. Most of the respondents came from the faculty of medicine, $23.3 \%$

An overview of depression, anxiety, and stress, in general, can be seen in Table 3. More college students are not depressed (55.0\%) or not stressed (57.4\%) than those who are depressed
Table 2 Characteristics of Respondents

\begin{tabular}{|c|c|}
\hline Characteristics & $n=258(\%)$ \\
\hline \multicolumn{2}{|l|}{ Age (years) } \\
\hline $15^{-19}$ & $36(13.9)$ \\
\hline $20-24$ & $220(85.3)$ \\
\hline $25-29$ & $2(0.8)$ \\
\hline \multicolumn{2}{|l|}{ Gender } \\
\hline Male & $91(35 \cdot 3)$ \\
\hline Female & $167(64.7)$ \\
\hline \multicolumn{2}{|l|}{ Origin } \\
\hline Sumatra & $49(19.0)$ \\
\hline Java & $157(60.8)$ \\
\hline Sulawesi & $29(11.2)$ \\
\hline Kalimantan & $16(6.2)$ \\
\hline Papua & $2(0.8)$ \\
\hline NTB & $3(1.2)$ \\
\hline Maluku & $2(0.8)$ \\
\hline \multicolumn{2}{|l|}{ Academic level } \\
\hline 1 & $47(18.2)$ \\
\hline 2 & $20(7.7)$ \\
\hline 3 & $172(66.7)$ \\
\hline 4 & $19(7.4)$ \\
\hline \multicolumn{2}{|l|}{ Living } \\
\hline With parents & $193(74.8)$ \\
\hline With others & $23(8.9)$ \\
\hline Alone & $42(16.3)$ \\
\hline \multicolumn{2}{|l|}{ Faculty } \\
\hline Economics & $34(13.2)$ \\
\hline Law & $1(0.4)$ \\
\hline Cultural Studies & $2(0.8)$ \\
\hline Communication Studies & $1(0.4)$ \\
\hline Education Science & $54(20.9)$ \\
\hline Political Science & $13(5.0)$ \\
\hline Medicine & $60(23.3)$ \\
\hline Public Health & $3(1.2)$ \\
\hline Nursing & $8(3.1)$ \\
\hline $\begin{array}{l}\text { Mathematics and Natural } \\
\text { Sciences }\end{array}$ & $8(3.1)$ \\
\hline $\begin{array}{l}\text { Agriculture and Animal } \\
\text { Husbandry }\end{array}$ & $11(4 \cdot 3)$ \\
\hline Psychology & $4(1.5)$ \\
\hline Fine Arts and Design & $1(0.4)$ \\
\hline Engineering & $21(8.1)$ \\
\hline Ushuluddin & $28(10.8)$ \\
\hline Others & $9(3.5)$ \\
\hline
\end{tabular}

or stressed. However, more students experience anxiety than those who are not anxious, $60.1 \%$.

Based on Table 4, most students experienced moderate depression, $12.8 \%$, very severe anxiety, 20.9\%, and severe stress, $13.6 \%$. 
Table 3 Overview of Depression, Anxiety, and Stress of College Students

\begin{tabular}{lc}
\hline Categories & Percentage \\
\hline Depression & \\
No & 55.0 \\
Yes & 45.0 \\
Anxiety & \\
No & 39.9 \\
Yes & 60.1 \\
Stress & \\
No & 57.4 \\
Yes & 42.6 \\
\hline
\end{tabular}

\section{Discussion}

In this study, $60.1 \%$ of respondents experienced anxiety. It is in line with the quantitative research by Hasanah et al., ${ }^{17}$ which shows most psychological problems college students encounter in online learning, is anxiety. A study by the Indonesian Mental Medicine Specialist Association (Perhimpunan Dokter Spesialis Kedokteran Jiwa Indonesia, PDSKJI) on mental health through self-examination showed $64.8 \%$ experienced anxiety. The average student anxiety rate in Indonesia during online learning is $40 \% .^{7}$ The category of anxiety in this study was the most, which was very severe (20.9\%). It is different from the online survey research by Rakhmanov and Dane ${ }^{14}$ on college students in Africa, which showed that the most anxiety category was mild, at $30 \%$. Another study by Wang et al. ${ }^{18}$ using a generalized anxiety disorder 7 (GAD-7) questionnaire on university students in the United States also showed different results. The category of most anxiety is mild at $33.27 \%$. The results of correlation analysis from research using the GAD-7 questionnaire on

Table 4 Overview of Depression, Anxiety, and Stress Levels of College Students

\begin{tabular}{lccc}
\hline Categories & Depression & Anxiety & Stress \\
\hline Mild & 11.6 & 7.4 & 10.3 \\
Moderate & 12.8 & 17.8 & 13.2 \\
Severe & 10.9 & 14.0 & 13.6 \\
Very severe & 9.7 & 20.9 & 5.4 \\
Total & 45.0 & 60.1 & 42.7 \\
\hline
\end{tabular}

college students from Changzhi medical college showed a positive relationship between barriers to academic activities and symptoms of anxiety $(\mathrm{p}<0.001) .{ }^{19}$

Anxiety is described as worry, anxiety, fear, restlessness, accompanied by various physical complaints..$^{20,21}$ Experiencing anxiety occasionally is a normal part of life. The most common symptoms and signs of anxiety are an unpleasant, vague sense of worry, often accompanied by autonomic symptoms such as headache, sweating, palpitations, tightness in the chest, mild abdominal complaints, and restlessness, indicated by an inability to sit or remain still for a long time. ${ }^{22}$

Anxiety disorders are related to genetic and experiential factors. The evidence clearly shows that traumatic and stressful life events are also the etiology of anxiety disorders. Anxiety disorders form one of the most common groups of psychiatric disorders. The prevalence of anxiety disorders in 12 months was $17.7 \%$. Women are more likely to experience anxiety disorders than men. The lifetime prevalence of women is $30.5 \%$, while that of men is $19.2 \%$. The majority of anxiety disorders decreases with higher socioeconomic status. ${ }^{22}$

The general description of depression in this study was $45.0 \%$. In contrast to the results of a survey by PDSKJI research on mental health through self-examination, $61.5 \%$ of respondents experience depression. ${ }^{7}$

By category, most respondents experienced moderate depression, which is $12.8 \%$. This study is not in line with research Wang et al. ${ }^{18}$ of the results of analysis patient health questionnaire 9 (PHQ-9) to college students in the United States, stating that most college students were in the category of mild depression, which is $32.45 \%$.

Depression is a common psychiatric disorder, with an estimated lifetime prevalence of $10 \%$ in the general population. Depression is more common in rural areas than in urban areas. ${ }^{22}$ According to the American Psychiatric Association, ${ }^{23}$ a diagnosis of a major depression episode (MDE) requires five or more symptoms to be present in 2 weeks. One of the symptoms must, at the very least, be depressed mood (DM) or anhedonia (loss of interest or pleasure- LI). Secondary symptoms of MDE are appetite or weight change (AW), difficulty sleeping (insomnia or hypersomnia), psychomotor agitation, or retardation (PAR). Other symptoms include fatigue or loss of energy 
(FE), reduced ability to think or concentrate (C), feelings of worthlessness or excessive guilt (FW), and suicide (SU). ${ }^{23-25}$

The general description of stress in this study is $42.7 \%$. In Indonesia, the average stress rate for college students during online learning is $55.1 \%{ }^{7}$ Studies in China states that a small portion of college students experience stress because of many tasks and complex of understanding the material. ${ }^{2}$

Based on the stress category, most respondents experienced severe stress, i.e., $13.6 \%$. In contrast to the descriptive study by Harahap et al., ${ }^{26}$ the average student experiences stress in the moderate category. The study results in a systematic review by Argaheni ${ }^{4}$ stated that most college students experienced mild stress, namely $38.57 \%$. The primary stressor is difficulty understanding material online. In contrast to the results of a previous descriptive study, which showed that most college students experienced mild stress, namely $40.3 \% .{ }^{27}$

A previous study states that several universities are still not ready to face online learning. The policy of temporarily closing educational institutions impacts college students, especially those who live in areas with limited infrastructure. It is one of the causes of increased stress and anxiety during the COVID-19 pandemic. Other factors that become stressors for college students are academic, economic, and family health concerns. Educational factors include adapting to online learning methods, the transition period of learning styles from high school to higher education, college assignments, and target achievement scores. Economic factors include concerns about not buying internet quota for online learning and limited job vacancies. These factors are by the results of previous studies that internal and external factors are stressors for college students during the COVID-19 pandemic. ${ }^{7}$

Stress comes from the Latin meaning tense or strained. Another definition literally, stress is a stimulus or situation that triggers negative emotions that create physical and psychological demands on individuals in the face of threats. ${ }^{27}$

Factors that can cause stress are called stressors. It can be physiological stressors (temperature, infection, pain), psychological stressors (worried, afraid, anxious, lonely, disappointed, falling in love), and socio-cultural stressors (divorce, unemployment, disputes). Stressors can cause positive (eustress) and negative (distress) changes. Prolonged stress can impact various aspects of a person's life, such as cognitive, emotional, behavioral, and physiological. Stress can cause psychological and psychological ailments, affecting performance at work, family, social life, drug addiction, and possibly criminal behavior. ${ }^{27}$

In this study, most of the respondents were in the age range of $20-24$ years. This study is similar to research conducted by PDSKJI through an online survey; the result is that psychological problems are most commonly found in the 17-29 year age group. ${ }^{7}$ The research results in China stated that people younger are at a higher risk of experiencing psychological problems than older people. It needs to be a concern because college students are included in the younger age group. ${ }^{2}$

There are problems at an even younger age. Globally, depression is one of the leading causes of disability in adolescents. Suicide is the fourth leading cause of death in the 15-19 year age range. ${ }^{28}$

College students belong to the young age group, under pressure from all aspects of life, such as academic demands, emotions, work, and others. Immature psychological development causes unstable emotions, psychological conflicts, and social problems. This pandemic situation exacerbates psychological conditions such as increased anxiety, fear, worry, and other negative emotions. ${ }^{29}$

In this study, the number of respondents was women more than men, i.e., $64.7 \%$. This research is in line with research by PDSKJI through an online survey which shows that there are more female respondents than males, namely $71 \% .7$ College students' anxiety scores about COVID-19 in Africa using a questionnaire survey were higher for women than men $(p=0.027){ }^{14}$ Research using the PHQ-9 questionnaire states that women are more at risk of depression, with an average female score of 1.76 points higher than men. ${ }^{18}$ The prevalence of the major depressive disorder is two times greater in women than in men. ${ }^{22}$

In dealing with stressors, women have lower coping abilities than men, which causes women to be more at risk of experiencing psychological disorders. In addition, most women have sensitive characteristics. Women have fear and tension higher than men and are also more concerned about the situation of the pandemic COVID-19. ${ }^{29}$

In this study, respondents mostly came from the island of Java, which is $60.8 \%$. Online learning is sometimes an obstacle for college students who live in remote areas. It is due 
to the limited internet coverage in the area. If this obstacle is not resolved, it can cause stress to college students because of the delay in the implementation of online learning. ${ }^{8}$ The challenges facing online learning are categorized into five: internet connection, hardware, economic conditions, difficulties in discussing with friends, and difficulties in interacting with lecturers. As many as $47 \%$ of college students feel that internet connection is an obstacle in online learning, while $18 \%$ think that internet connection is not an obstacle. Indonesia is an archipelagic country with unequal internet coverage. ${ }^{30}$

In this study, most of the respondents were at level 3, 66.7\%. There was no significant difference in student anxiety based on an academic level $(p=0.813)$. Each group has its difficulties which can have an impact on psychological problems. Depression, stress, and anxiety usually occur in level 1 and 2 college students because they are still adapting to the transition period from high school to higher education, while levels 3 and 4 are due to thesis and internship guidance as graduation requirements in several faculties. During the pandemic, only a few companies can accept college students for internships and data collection..$^{30}$

In this study, most respondents lived with their parents, $74.8 \%$. As for those who live with other people, namely in boarding schools, dormitories, relatives, while those who live alone, namely in boarding houses, own homes, prayer rooms, mosques. Most college students prefer to study at home because it is comfortable. ${ }^{3}$ One of the stressors for college students is the extended distance from their parents and relatives. ${ }^{7}$ College students who study away from their families during the pandemic are afraid of being infected with COVID-19 and worried that they would not see their families again. They also worry about their families' safety and health, which can affect them psychosocially. ${ }^{8}$ In contrast to other studies, college students who live with their parents are involved in helping their parents; some have to work, causing anxiety when they cannot participate in online learning optimally. 2

In this study, most respondents, $23.3 \%$, came from the faculty of medicine. Under normal conditions, medical college students have a busy class schedule and a heavy study load. With the pandemic, college students must adapt to online learning. If there are obstacles in adaptation such as internet connection disorders, a less conducive learning environment, and others, it causes anxiety in college students. Research by NurCita and Susantiningsih ${ }^{20}$ regarding the anxiety level of the college students of the Faculty of Medicine Universitas Pembangunan Nasional Veteran Jakarta in 2020 stated that $88 \%$ of college students experienced severe anxiety levels. In another study, there was no difference in the level of anxiety between faculties. ${ }^{14}$

\section{Conclusion}

This study concludes that most college students experience moderate depression, very severe anxiety, and severe stress.

\section{Conflict of Interest}

The authors declare no conflict of interest.

\section{Acknowledgment}

We acknowledge all college students who have participated in this research.

\section{References}

1. Ratunuman RA, David LEV, Opod H. Dampak psikologis pandemi COVID-19 pada mahasiswa. J Biomedik. 2021;13(2):227-32.

2. Ulfa ZD, Mikdar UZ. Dampak pandemi Covid-19 terhadap perilaku belajar, sosial dan kesehatan bagi mahasiswa FKIP Universitas Palangka Raya. JOSSAE. 2020;5(2):124-38.

3. Onyema EM, Eucheria NC, Obafemi FA, Sen S, Atonye FG, Sharma A, et al. Impact of coronavirus pandemic on education. JEP. 2020;11(13):108-21.

4. Argaheni NB. Sistematik review: dampak perkuliahan daring saat pandemi COVID-19 terhadap mahasiswa Indonesia. Placentum. 2020;8(2):99-108.

5. Warsita B. Pola kegiatan pembelajaran dalam pendidikan jarak jauh. J Teknodik. 2014;18(1)73-83.

6. XieX, Siau K, Nah FFH.COVID-19 pandemiconline education in the new normal and the next normal. JITCAR. 2020;22(3):175-87.

7. Fauziyyah R, Awinda RC, Besral. Dampak pembelajaran jarak jauh terhadap tingkat stres dan kecemasan mahasiswa selama pandemi COVID-19. BIKFOKES. 2021;1(2): $113-23$.

8. Khan KS, Mamun MA, Griffiths MD, Ullah I. The mental health impact of the COVID-19 
pandemic across different cohorts. Int $\mathrm{J}$ Ment Heal Addict. 2020:1-7.

9. Liu $\mathrm{CH}$, Pinder-Amaker S, Hahm HC, Chen JA. Priorities for addressing the impact of the COVID-19 pandemic on college student mental health. J Am Coll Health. 2020:1-3.

10. Irawan AW, Dwisona, Lestari M. Psychological Impacts of students on online learning during the pandemic COVID-19. Konseli. 2020;7(1):53-60.

11. Deliviana E, Erni MH, Hilery PM, Naomi NM. Pengelolaan kesehatan mental mahasiswa bagi optimalisasi pembelajaran online di masa pandemi Covid-19. J Selaras. 2020;3(2):129-38.

12. Chakraborty P, Mittal P, Gupta MS, Yadav S, Arora A. Opinion of students on online education during the COVID-19 pandemic. Hum Behav Emerg Technol. 2021;3(3):35765.

13. Widyastuti, Maryam EW. Sense of community dan wellness pada mahasiswa (studi pada Universitas Muhammadiyah Sidoarjo). Psycho Idea. 2019;17(1):1-8.

14. Rakhmanov O, Dane S. Knowledge and anxiety levels of African university students against covid-19 during the pandemic outbreak by an online. J Res Med Dent Sci. 2020;8(3):53-6.

15. Damanik ED. Depression anxiety stress scales (DASS) Damanik translation bahasa Indonesia [Internet]. Sydney: University of New South Wales; 2018 [cited 2021 August 10]. Available from: http://www2.psy.unsw. edu.au/dass/Indonesian/Damanik.htm.

16. Healthfocus Clinical Psychology Services. Depression anxiety and stress scale DASS (-42) [Internet]. Armadale: Healthfocus Clinical Psychology Services; 2018 [cited 2021 August 12]. Available from: https:// www.healthfocuspsychology.com.au/tools/ dass-42.

17. Hasanah U, Ludiana, Immawati, Livana PH. Gambaran psikologis mahasiswa dalam proses pembelajaran selama pandemi Covid-19. JKK. 2020;8(3):299-306.

18. Wang X, Hegde S, Son C, Keller B, Smith A, Sasangohar F. Investigating mental health of US college students during the COVID-19 pandemic: cross-sectional survey study. J Med Internet Res. 2020;22(9):e22817.

19. Cao W, Fang Z, Hou G, Han M, Xu X, Dong
$\mathrm{J}$, et al. The psychological impact of the COVID-19 epidemic on college students in China. Psychiatry Res. 2020;287:112934.

20. NurCita B, Susantiningsih T. Dampak pembelajaran jarak jauh dan physical distancing pada tingkat kecemasan mahasiswa. J Borneo Holist Health. 2020; 3(1):58-68.

21. American Psychological Association. Anxiety [Internet]. Washington: American Psychological Association; 2021 [cited 2021 Aug 10]. Available from: https://www.apa. org/topics/anxiety.

22. Sadock BJ, Sadock VA, Ruiz P. Kaplan \& Sadock's concise textbook of clinical psychiatry. $4^{\text {th }}$ Edition. Philadelphia: Wolters Kluwer; 2017.

23. American Psychiatric Association. Diagnostic and statistical manual of mental disorders. $5^{\text {th }}$ Edition. Arlington: American Psychiatric Association; 2013.

24. Tolentino JC, Schmidt SL. DSM-5 criteria and depression severity: implications for clinical practice. Front Psychiatry. 2018;9:450.

25. Maslim R. Diagnosis gangguan jiwa rujukan ringkas dari PPDGJ-III dan DSM-5. Jakarta: PT Nuh Jaya; 2013.

26. Harahap ACP, Harahap DP, Harahap SR. Analisis tingkat stres akademik pada mahasiswa selama pembelajaran jarakjauh di masa Covid-19. Biblio Couns. 2020;3(1):104.

27. Jannah R, Santoso H. Tingkat stres mahasiswa mengikuti pembelajaran daring pada masa pandemi Covid-19. JRPM. 2021;1(1):130-46.

28. World Health Organization. Adolescent mental health [Internet]. Geneva: World Health Organization; 2021 [cited 2021 August 9]. Available from: https://www.who.int/ news-room/fact-sheets/detail/adolescentmental-health.

29. Liu X, Liu J, Zhong X. Psychological state of college students during COVID-19 epidemic. Lancet Glob Health [preprint]. 2020 [posted 2020 October 3; cited 2021 August 9]; [22 p.]. Available from: https://ssrn.com/ abstract $=3552814$.

30. Yanti MP, Nurwulan NR. Pengaruh pembelajaran daring pada depresi, stres, dan kecemasan mahasiswa. J Muara Pendidikan. 2021;6(1):58-63. 